\title{
Diet Rich in Lard Promotes a Metabolic Environment Favorable to Trypanosoma cruzi Growth
}

\section{OPEN ACCESS}

Edited by:

Livia Passos,

Brigham and Women's Hospital and Harvard Medical School, United States

Reviewed by: Ana Carolina Leao, Baylor College of Medicine,

United States

Amelie Vromman,

Brigham and Women's Hospital and

Harvard Medical School, United States

*Correspondence: André Talvani

talvani@ufop.edu.br

tThese authors have contributed equally to this work

Specialty section

This article was submitted to General Cardiovascular Medicine, a section of the journal

Frontiers in Cardiovascular Medicine

Received: 13 February 2021 Accepted: 15 April 2021 Published: 25 May 2021

Citation:

Souza DMS, Silva MC, Farias SEB, Menezes APJ, Milanezi CM, Lúcio KP, Paiva NCN, Abreu PM, Costa DC, Pinto KMC, Costa GP, Silva JS and

Talvani A (2021) Diet Rich in Lard Promotes a Metabolic Environment Favorable to Trypanosoma cruzi

Front. Cardiovasc. Med. 8:667580. doi: $10.3389 /$ fcrm.2021.667580

\begin{abstract}
Débora Maria Soares de Souza ${ }^{1,2,3 \dagger}$, Maria Cláudia Silva ${ }^{4 \dagger}$, Silvia Elvira Barros Farias ${ }^{1}$, Ana Paula de J. Menezes ${ }^{1}$, Cristiane Maria Milanezi ${ }^{4}$, Karine de P. Lúcio ${ }^{5}$, Nívia Carolina N. Paiva ${ }^{6}$, Paula Melo de Abreu ${ }^{2}$, Daniela Caldeira Costa ${ }^{3,5}$, Kelerson Mauro de Castro Pinto ${ }^{1,7}$, Guilherme de Paula Costa ${ }^{1,3}$, João Santana Silva ${ }^{4,8}$ and André Talvani ${ }^{1,3,9 *}$
\end{abstract}

${ }^{1}$ Laboratory of Immunobiology of Inflammation, Department of Biological Sciences, Federal University of Ouro Preto, Ouro Preto, Brazil, ${ }^{2}$ Biological Science Post-graduate Program, Federal University of Ouro Preto, Ouro Preto, Brazil, ${ }^{3}$ Health and Nutrition Post-graduate Program, Federal University of Ouro Preto, Ouro Preto, Brazil, ${ }^{4}$ Department of Biochemistry and Immunology, Ribeirão Preto Medical School, University of São Paulo, São Paulo, Brazil, ${ }^{5}$ Laboratory of Metabolic Biochemistry, Department of Biological Sciences, Federal University of Ouro Preto, Ouro Preto, Brazil, ${ }^{6}$ Center of Research in Biological Sciences, Federal University of Ouro Preto, Ouro Preto, Brazil, ${ }^{\top}$ School of Physical Education, Federal University of Ouro Preto, Ouro Preto, Brazil, ${ }^{8}$ Fiocruz-Bi-Institutional Translational Medicine Plataform, Ribeirão Preto Medical School, University of São Paulo, São Paulo, Brazil, ${ }^{9}$ Health Science, Infectology and Tropical Medicine Post-graduate Program, Federal University of Minas Gerais, Belo Horizonte, Brazil

Background: Trypanosoma cruzi is a protozoan parasite that causes Chagas disease and affects 6-7 million people mainly in Latin America and worldwide. Here, we investigated the effects of hyperlipidic diets, mainly composed of olive oil or lard on experimental T. cruzi infection. C57BL/6 mice were fed two different dietary types in which the main sources of fatty acids were either monounsaturated (olive oil diet) or saturated (lard diet).

Methods: After 60 days on the diet, mice were infected with 50 trypomastigote forms of $T$. cruzi Colombian strain. We evaluated the systemic and tissue parasitism, tissue inflammation, and the redox status of mice after 30 days of infection.

Results: Lipid levels in the liver of mice fed with the lard diet increased compared with that of the mice fed with olive oil or normolipidic diets. The lard diet group presented with an increased parasitic load in the heart and adipose tissues following infection as well as an increased expression of TIr2 and TIr9 in the heart. However, no changes were seen in the survival rates across the dietary groups. Infected mice receiving all diets presented comparable levels of recruited inflammatory cells at 30 days post-infection but, at this time, we observed lard diet inducing an overproduction of CCL2 in the cardiac tissue and its inhibition in the adipose tissue. T. cruzi infection altered liver antioxidant levels in mice, with the lard diet group demonstrating decreased catalase (CAT) activity compared with that of other dietary groups.

Conclusions: Our data demonstrated that T. cruzi growth is more favorable on tissue of mice subjected to the lard diet. Our findings supported our hypothesis of a relationship between the source of dietary lipids and parasite-induced immunopathology.

Keywords: inflammation, Trypanosoma cruzi, saturated fatty acids, monounsaturated fatty acids, adipose tissue, cardiac tissue 


\section{INTRODUCTION}

The protozoan Trypanosoma cruzi, the etiological agent of Chagas' disease, affects 6-7 million people worldwide (1). The parasite triggers an intense tissue inflammatory response in the mammalian host $(2,3)$, which culminates in damage to cardiac cells. The progressive myocarditis is associated with high mortality and morbidity rates $(4,5)$.

In the absence of an effective pharmacological treatment against the $T$. cruzi, there has been a growing demand for methods that control the parasite replication and regulate the parasite induced immune response to minimize tissue damage in infected hosts (6). In this sense, it has been argued that the nutritional status and dietary quality might be of importance for the regulation of the host immune responses and in the progression of infection (7-9). Diets rich in saturated fatty acids have been linked to increasing adiposity and comorbidities such as diabetes, hypertension, atherosclerosis, as well as interfering in the immune response that favor the growth of T. cruzi $(10,11)$. Diets rich in monounsaturated and polyunsaturated fatty acids are beneficial to the body as they improve cardiac function and modulate the immune system $(12,13)$.

Considering that T. cruzi infection causes a chronic systemic and cardiac pattern of inflammatory response, and different lipids are present in the intra- and extracellular environmental of the parasites, the present study we aimed to investigate the interference of monounsaturated and saturated fatty acid diets in the course of T. cruzi infection related inflammation.

\section{MATERIALS AND METHODS}

\section{Ethical Approval}

All the methodologies performed are in accordance with the standards of the National Council for Control of Animal Experimentation (CONCEA), and were previously approved by the Animal Research Ethics Committee of the Federal University of Ouro Preto (CEUA-UFOP), under the protocol number $36 / 2015$. The experiments comply with the standards of animal research explicit in Law 11.749, of 2008, regulated by Decree No. 6.899 , of July $15,2009$.

\section{Animals, Study Design, and Diets}

C57BL/6 male mice aged 21-days were used. The animals were divided into groups according to the composition of diet they received: normolipidic diet, monounsaturated fatty acid diet with olive oil (olive oil diet) and saturated fatty acid diet with lard (lard diet) (Table 1). The diets administration was initiated after weaning and, after 60 days of diet, mice were infected with $T$. cruzi. The analyses were performed at the day 30 post infection (30 dpi), except in three independent experiments in which the survival rate and the blood parasitemia were followed by 60 days, the period when the number of parasites in the blood decreased.

\section{Food Intake and Lee's Index}

The food intake was calculated by weighting the food provided every other day divided by the number of mice in the cage. The food intake (g) multiplied by the calorie provided, according to
TABLE 1 | Diet composition (1,000 g).

\begin{tabular}{|c|c|c|c|}
\hline Ingredients (g) & Control diet & $\begin{array}{l}\text { Hyperlipidic } \\
\text { diet-Olive oil } \\
\text { (DOO) }\end{array}$ & $\begin{array}{c}\text { Hyperlipidic } \\
\text { diet-Lard } \\
\text { (DL) }\end{array}$ \\
\hline Corn starch & 465.7 & 287.7 & 287.7 \\
\hline Casein & 140.0 & 140.0 & 140.0 \\
\hline Dextrinized starch & 155.0 & 155.0 & 155.0 \\
\hline Sucrose & 100.0 & 100.0 & 100.0 \\
\hline Soy oil & 40.0 & 40.0 & 40.0 \\
\hline Microcrystalline cellulose & 50.0 & 50.0 & 50.0 \\
\hline Mineral mix AIN93Mª & 35.0 & 35.0 & 35.0 \\
\hline Vitamin mix AIN93M & 10.0 & 10.0 & 10.0 \\
\hline L-cysteine & 1.8 & 1.8 & 1.8 \\
\hline Choline Bitartrate & 2.5 & 2.5 & 2.5 \\
\hline Lard $^{\mathrm{C}}$ & - & - & 168.0 \\
\hline Cholesterol & - & - & 10.0 \\
\hline Extra virgin olive oild & - & 178.0 & - \\
\hline Total caloric value $/ 1,000 \mathrm{~g}$ & 4020.0 & 4910.0 & 4910.0 \\
\hline
\end{tabular}

a Minerals (g/kg): $\mathrm{CaCO}_{3} 357.0 / \mathrm{C}_{6} \mathrm{H}_{5} \mathrm{~K}_{3} \mathrm{O}$ 7. $\mathrm{H}_{2} \mathrm{O} 28.0 / \mathrm{KH}_{2} \mathrm{PO}_{4} 250.0 / \mathrm{NaCl} 74.0 / \mathrm{K}_{2} \mathrm{SO}_{4}$ 46.6/MgO 24.0/ $\mathrm{C}_{6} \mathrm{H}_{5}+4 . \mathrm{FexNyO}_{7} \quad 6.06 / \mathrm{CO}_{3} \mathrm{Zn} \quad 1.65 / \mathrm{MnCO}_{3} \quad 0.63 / \mathrm{CuCO}_{3} \quad 0.3 / \mathrm{KI}$ $0.01 / \mathrm{Na}_{2} \mathrm{Se} 0.01025 /\left(\mathrm{NH}_{4}\right) 6 \mathrm{Mo}_{7} \mathrm{O}_{2} 4.4 \mathrm{H}_{2} \mathrm{O} 0.00795 / \mathrm{Na}_{2} \mathrm{SiO}_{3} .9 \mathrm{H}_{2} \mathrm{O} \quad 1.45 / \mathrm{KCr}\left(\mathrm{SO}_{4}\right)$

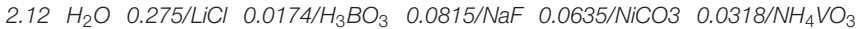
$0.0066 / \mathrm{C}_{12} \mathrm{H}_{2} \mathrm{O}_{11} 209.806$.

${ }^{b}$ Vitamins $(\mathrm{mg} / \mathrm{kg})$ : Niacin 3.0/Calcium pantothenate 1.6/Pyridoxine 0.7/Thiamine 0.6/Riboflavin 0.6/Folic acid 0.2/Biotin 0.02/Vitamin E (500 /U/g) 15.0/Vitamin B12 (0.1\%) 2.5/Vitamin A $(500,000 \mathrm{lU} / \mathrm{g})$ 0.8/Vitamin D3 (400,000 IU/g) 0.25/Vitamin K1/Dextrose Mix (10 mg/g) 7.50/Sucrose 967.23. Conversion factors: proteins $4 \mathrm{kcal} / \mathrm{g}$, lipids $9 \mathrm{kcal} / \mathrm{g}$, sugars $4 \mathrm{kcal} / \mathrm{g}$.

${ }^{c}$ Fatty acid composition of lard (commercial name: Estrela-values referring to $100 \mathrm{~g}$ of the product): saturated 40.0/monounsaturated 44.76/polyunsaturated 15.42.

${ }^{d}$ Fatty acid composition of extra virgin olive oil (commercial name: Olivenza-values referring to $100 \mathrm{~g}$ of product): saturated 14.9/monounsaturated 75.6/polyunsaturated 9.5.

the offered diet) indicates the calorie intake. The Lee's index, indicator of obesity in rodents, proposed by Lee (14) and described by Bernardis and Petterson (15), was calculated by dividing the cubic root of body weight $(\mathrm{g}$ ) by the naso-anal length $(\mathrm{cm})$ and multiplied the result by 10 .

\section{Biochemical Testing}

Total cholesterol and triglycerides were determined using commercial kits from Bioclin ${ }^{\circledR}$ (Belo Horizonte, MG, Brazil) according to protocols available by the manufacturer.

\section{Liver Total Lipids Quantification}

The total lipids in the liver were quantified according to Folch method. Briefly, $100 \mathrm{mg}$ liver tissue was macerated in $400 \mathrm{~mL}$ of chloroform/methanol $(2: 1)$ and centrifuged at 3,000 g, for $10 \mathrm{~min}$ at $22^{\circ} \mathrm{C}$. Following this, $800 \mathrm{~mL}$ of chloroform and $640 \mathrm{~mL}$ of $\mathrm{NaCl}(0.73 \%)$ were added to the supernatant, and samples were centrifuged at $3,000 \mathrm{rpm}$, for $10 \mathrm{~min}$ at $22^{\circ} \mathrm{C}$. The lower phase was washed three times with $600 \mathrm{~mL}$ of Folch solution (a solution of distilled water containing 48\% methanol, 3\% chloroform, and $2 \% \mathrm{NaCl}$ at $0.29 \%$ ) and the extracted lipids were dried overnight at $50^{\circ} \mathrm{C}$. The amount of lipid of each sample was calculated by the difference between the weight of samples before and after they were dried. 


\section{Mice Infection, Parasitemia, Survival Rate, and Body Weight}

Mice were inoculated intraperitoneally with 50 blood trypomastigote forms of the Colombian strain of T. cruzi, obtained after two consecutive passages of the strain in swiss mice. After the infection, the blood parasitemia levels were evaluated daily by counting the number of parasites in $5 \mathrm{ml}$ tail-vein blood samples using an optical microscope. Mortality rate among the groups of animals was updated daily. In addition, the body weight was assessed daily by weighing the animals on a digital scale.

\section{DNA Extraction and Parasitism Analysis}

The genomic DNA was extracted from $10 \mathrm{mg}$ of heart or adipose tissue using the Wizard ${ }^{\circledR}$ SV Genomic DNA Purification System kit (Promega) according to the manufacturer's instructions. Realtime polymerase chain reaction (PCR) was performed to quantify the heart parasitism as previously described (16).

\section{Histology}

To determine the number of cells infiltrated in the heart and epididymal adipose tissue, small pieces of the tissues were fixed in dimethyl sulfoxide (DMSO)-Methanol (1:5) for 30 days, dehydrated through successive incubations in crescent concentrations of ethanol, cleared in xylol and fixed in plastic paraffin (Paraplast ${ }^{\circledR}$ ). The paraffin-fixed tissues were cut into sections with a size of $4 \mu \mathrm{m}$, stained with hematoxylin and eosin (HE) and the cell nuclei present in the fragments were quantified in 20 images (random fields). The images visualized by the $40 \mathrm{X}$ objective were scanned through the Leica DM 5000 B (Leica Application Suite, version 2.4.0R1) and processed through the Leica Qwin V3 image analyzer program.

\section{Quantitative Real-Time PCR}

Total RNA from the heart and epididymal adipose tissue was extracted using the TRIzol reagent (Invitrogen) and the SV Total RNA Isolation System kit (Promega) according to the manufacturer's instructions. Complementary DNA was synthesized from $500 \mathrm{ng}$ of RNA through a High Capacity cDNA Reverse Transcription kit (Applied Biosystems). Realtime PCR assays were performed in a StepOnePlus Real-Time PCR System (Applied Biosystems) using SYBR Green Mix reagents (Invitrogen). The mean cycle threshold $(\mathrm{Ct}$ ) values from duplicate measurements were used to calculate the expression of the two target genes, which were normalized to the housekeeping genes GAPDH or $18 \mathrm{~S}$. The sequences of all primers used are described in Table 2.

\section{Immunoassay}

Levels of CCL2 were detected in the supernatant of the homogenized cardiac and adipose tissues. For sample preparation, $20 \mathrm{mg}$ of heart and $40 \mathrm{mg}$ of epididymal adipose tissues were macerated in $200 \mathrm{~mL}$ of phosphate buffered saline (PBS) and, after centrifugation at $1,500 \mathrm{~g}$, for $10 \mathrm{~min}$ at $4^{\circ} \mathrm{C}$, the supernatant was collected. Inflammatory mediators were measured by enzyme-linked immunosorbent assay (ELISA) using a specific kit (Peprotech ${ }^{\circledR}$ ) and were performed according
TABLE 2 | Sequences of the primers used.

\begin{tabular}{|c|c|}
\hline Targets & Sequences \\
\hline TIr2 & $\begin{array}{l}\text { Forward: AAGTCTCCGGAATTATCAGTCC } \\
\text { Reverse: TGATGGATGTCGCGGAT }\end{array}$ \\
\hline TIr9 & $\begin{array}{l}\text { Forward: GGACCTACAGCAGAATAGCTCA } \\
\text { Reverse: AACTCGGGAACCAGACATG }\end{array}$ \\
\hline T. cruzi & $\begin{array}{l}\text { Forward: AAATAATGTACGGG(T/G)GAGATGCATGA } \\
\text { Reverse: GGGTTCGATTGGGGTTGGTGT }\end{array}$ \\
\hline $18 S$ & $\begin{array}{l}\text { Forward: CCGCAGCTAGGAATAATGGAATA } \\
\text { Reverse: GCCTCAGTTCCGAAAACCAA }\end{array}$ \\
\hline Gapdh & $\begin{array}{l}\text { Forward: GTGGAGTCATACTGGAACATGTAG } \\
\text { Reverse: AATGGATGAAGGTCGGTGTG }\end{array}$ \\
\hline
\end{tabular}

to the manufacturer's information. The absorbance values were measured using the eMax ELISA reader (Molecular Devices) at $450 \mathrm{~nm}$.

\section{Catalase Activity Assay}

Catalase activity was determined as described by Aebi (17) based on its ability to convert hydrogen peroxide $\left(\mathrm{H}_{2} \mathrm{O}_{2}\right)$ into water and molecular oxygen. Briefly, $100 \mathrm{mg}$ liver tissue was macerated in $1 \mathrm{~mL}$ of $0.1 \mathrm{M}$ phosphate buffer, $\mathrm{pH} 7.2$, centrifuged at $10,000 \mathrm{~g}$, $10 \mathrm{~min}$ at $4{ }^{\circ} \mathrm{C}$. For the assay, $10 \mu \mathrm{L}$ of the supernatant was added in $50 \mu \mathrm{L}$ of $\mathrm{K}_{2} \mathrm{HPO}_{4}, 40 \mu \mathrm{L}$ of milli-Q water (Millipore, Bedford, MA) and $900 \mu \mathrm{L}$ of $2.5 \mathrm{mmol} / \mathrm{L} \mathrm{H}_{2} \mathrm{O}_{2}$. The enzyme activity was measured at $240 \mathrm{~nm}$ at $30 \mathrm{~s}, 2$ and $3 \mathrm{~min}$ by decaying the absorbances. One-unit $(\mathrm{U})$ of catalase is equivalent to the hydrolysis of $1 \mathrm{mmol}$ of $\mathrm{H}_{2} \mathrm{O}_{2}$ per minute.

\section{Superoxide Dismutase Activity}

Pyrogallol undergoes autoxidation producing the superoxide anion $\left(\mathrm{O}^{-}\right)$. The SOD enzyme competes for the $\mathrm{O}^{-}$by decreasing the 3-(4,5-Dimethylthiazol-2-yl) (MTT) reduction. For the assay, the supernatant of $100 \mathrm{mg}$ of liver tissue was mixed with MTT and pyrogallol and incubated at $37^{\circ} \mathrm{C}$ for $5 \mathrm{~min}$. The reaction was stopped with DMSO and the plate was read at $570 \mathrm{~nm}$. The results were expressed as $\mathrm{U}$ of SOD per mg of protein in the supernatant of the liver tissue. One unit of SOD is defined as the amount of enzyme required for $50 \%$ inhibition of MTT reduction.

\section{Oxidized and Total Glutathione Quantification Assay}

For the dosage of oxidized glutathione (GSSG), we used a standard solution of $10 \mathrm{mM}$ oxidized glutathione for the samples and a standard solution of $50 \mathrm{mM}$ oxidized glutathione in $5 \%$ sulfosalicylic acid (SSA) for the curve. The samples were obtained from the supernatant of $100 \mathrm{mg}$ of liver homogenized in $1 \mathrm{~mL}$ of $5 \%$ sulfosalicylic acid buffer - SSA. Following this, $100 \mu \mathrm{L}$ of the samples were pipetted in $50 \mathrm{~mL}$ tubes and pipetted between 0.5 and $2.0 \mu \mathrm{L}$ of vinylpyridine and $1-5 \mu \mathrm{L}$ of triethanolamine (TEA) was added to maintain the $\mathrm{pH}$ between 6.0 and 7.0. The tubes were filled with distilled water to a volume of $15 \mathrm{~mL}$, homogenized and kept at room temperature for $1 \mathrm{~h}$. After the incubation, $10 \mu \mathrm{L}$ of samples were measured at $412 \mathrm{~nm}$. The samples were incubated for additional $5 \mathrm{~min}$ at room temperature 
and, afterwards, $50 \mu \mathrm{L}$ of nicotinamide adenine dinucleotide phosphate (NADPH) was added. The plate was read each $1 \mathrm{~min}$ during the $5 \mathrm{~min}$ incubation. Oxidized glutathione in the samples was calculated based on pre-defined concentrations for the calibration curve (p1: 0.25, p2: 0.125, p3: 0.062, p4: 0.0312, p5: 0.0156). For the measurement of total glutathione, $10 \mu \mathrm{L}$ of samples were pipetted in a 96-well plate and immediately after the addition of $50 \mu \mathrm{L}$ of NADPH, the absorbances were read each $1 \mathrm{~min}$ during the $5 \mathrm{~min}$ incubation. The values for reduced glutathione $(\mathrm{GSH})$ were obtained from the difference between total and oxidized glutathiones.

\section{Statistical Analysis}

Data were expressed as means \pm SEM. Multiple groups were compared using one-way analysis of variance (ANOVA) followed by Tukey-Kramer post-test. The survival rate was compared by log-rank test (Mentel-Cox) and the student's $t$-test was used to compare differences among two experimental groups. All analyzes were performed using the Prism 8 software (GraphPad Software). Groups were considered statistically different when $p$-values $<0.05$.

\section{RESULTS}

\section{Hyperlipidic Diet Alters Body and Biochemical Parameters in Mice}

Firstly, we evaluated if the intake of normal and hyperlipidic diets, and the calories provided by diets were similar among the groups. To address this point, newly weaned mice were fed with either a normolipidic diet, monounsaturated fatty acid diet (olive oil) or with a saturated fatty acid diet (lard) for 90 days. None of them modified mice's body weight (Figure 1A). Although mice fed with normolipidic diet consumed a higher quantity of food than groups fed with olive oil or lard diets (Figure 1B), the calorie intake was similar among all animals (Figure 1C). The effect of hyperlipidic diets on the biochemical and body parameters of mice were also evaluated. The liver/body weight ratio was not different among animals receiving distinct diets (Figure 1D) and mice fed a lard diet presented higher amount of liver lipids when compared to those fed with normolipidic and olive oil diets (Figure 1E). We observed a decreased plasma levels of total cholesterol in mice fed with olive oil and lard diets (Figure 1F) while triglycerides level was similar among all animals (Figure 1G). The Lee's index, an indicative degree of obesity in mice (18), was similar among all animals (Figure $\mathbf{1 H}$ ), but the weight of the epididymal and subcutaneous adipose tissues was higher in association with the lard diet (Figure 1I).

\section{Diet Composition Interferes With the Heart and Adipose Tissue Parasitism After T. cruzi Infection}

To evaluate if the olive oil diet or lard diet would affect the response against the Colombian strain of $T$. cruzi, mice were infected after 60 days of diet. The number of parasites circulating in the mice blood was similar between the infected animals in all days evaluated (Figure 2A); the difference was not evident even during the peak of the parasitemia, at day 27 post infection (Figure 2B). Interestingly, at the day 30 post infection, mice fed with the lard diet presented higher parasitism in the heart (Figure 2C) and adipose tissue (Figure 2D) compared to the mice fed with normolipidic diet or olive oil diet. Despite the high number of parasites among the group fed with lard diet, the percentage of survival was not different between the groups that received the different types of diet (Figure 2E).

\section{Increased Amount of Olive Oil or Lard in the Diet Did Not Alter the Tissue Inflammation After T. cruzi Infection}

Since mice fed with lard diets presented with high tissue parasitism, we investigated whether the diets interfere with the migration of inflammatory cells to the heart and adipose tissue following infection. For this purpose, after 60 days of either normolipidic, olive oil or lard diets followed by $30 \mathrm{dpi}$ with T. cruzi Colombian strain, the production of the chemokine CCL2 and the tissue inflammation were evaluated. The infection increased the CCL2 production in the heart tissue (Figure 3A) and the number of inflammatory cells infiltrating the tissue (Figures 3B,C) independently of the diet administered. Although the lard diet increases the heart CCL2 production after infection compared with infected normolipidic group, the number of inflammatory cells in the tissue is similar among the infected groups independent of the dietary type (Figures 3B,C). Mice fed with the normolipidic diet presented with an increased production of CCL2 in adipose tissue after infection compared to all other dietary group (Figure 4A) despite this, the tissue inflammation increased similarly for all groups (Figures $4 \mathrm{~A}-\mathrm{C}$ ).

\section{Hyperlipidic Diet Rich in Olive Oil Increases Toll-Like Receptors Expression in the Cardiac Tissue After T. cruzi Infection}

Since TLRs are particularly important for parasite recognition by immune cells, we investigated whether the hyperlipidic diets could interfere with the TLR expression in the cardiac and adipose tissue cells after T. cruzi infection. After receiving either normolipidic, olive oil or lard diets for 60 days, mice were infected by Colombian strain of T. cruzi and the mRNA expression levels of Tlr2 and Tlr9 were evaluated in the cardiac and adipose tissues of infected and non-infected mice. Infected mice fed with olive oil diet presented higher Tlr2 and Tlr9 expression in the heart (Figures 5A,B) while those fed with lard diet presented higher Tlr2 and Tlr9 expression in the adipose tissue (Figures 5C,D).

\section{Hyperlipidic Diet Alters the Redox Status After T. cruzi Infection}

The T. cruzi infection-caused oxidative stress, resulting in the accumulation of free radicals, which altered the expression and/or activity of antioxidant enzymes such as oxidized glutathione (GSSG), catalase (CAT), and superoxide dismutase (SOD). Activities of GSSG, CAT and SOD were evaluated in the liver of mice fed with either a control, olive oil, or lard diet for 60 days, followed by $30 \mathrm{dpi}$ with T. cruzi. The infection 
A

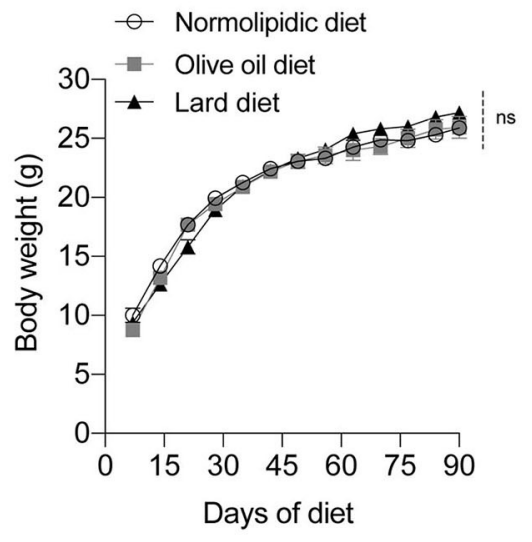

D

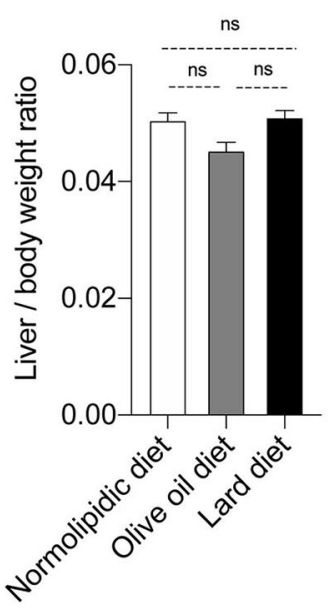

G

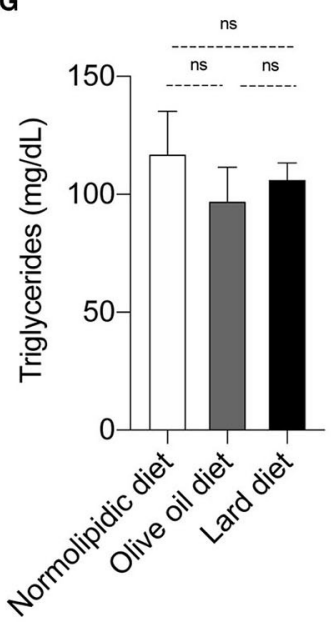

H
B

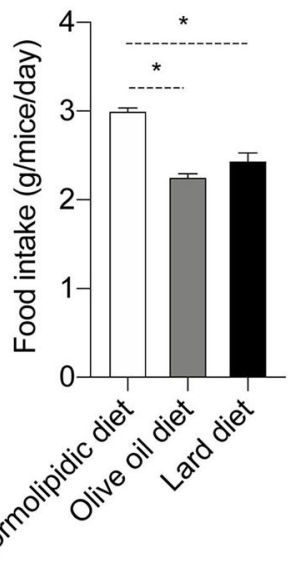

E

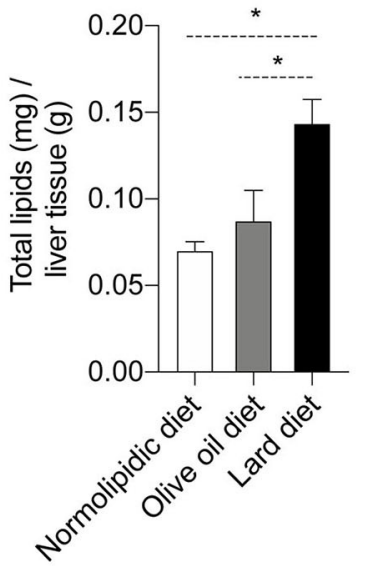

C

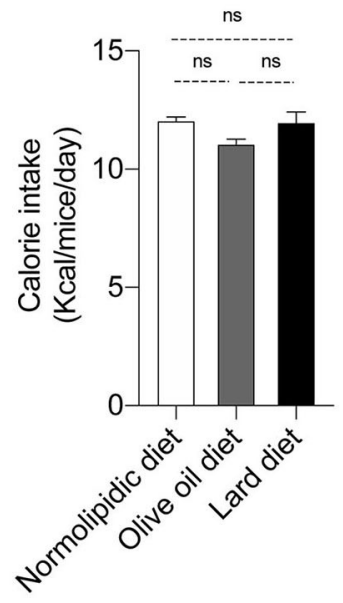

$\mathbf{F}$
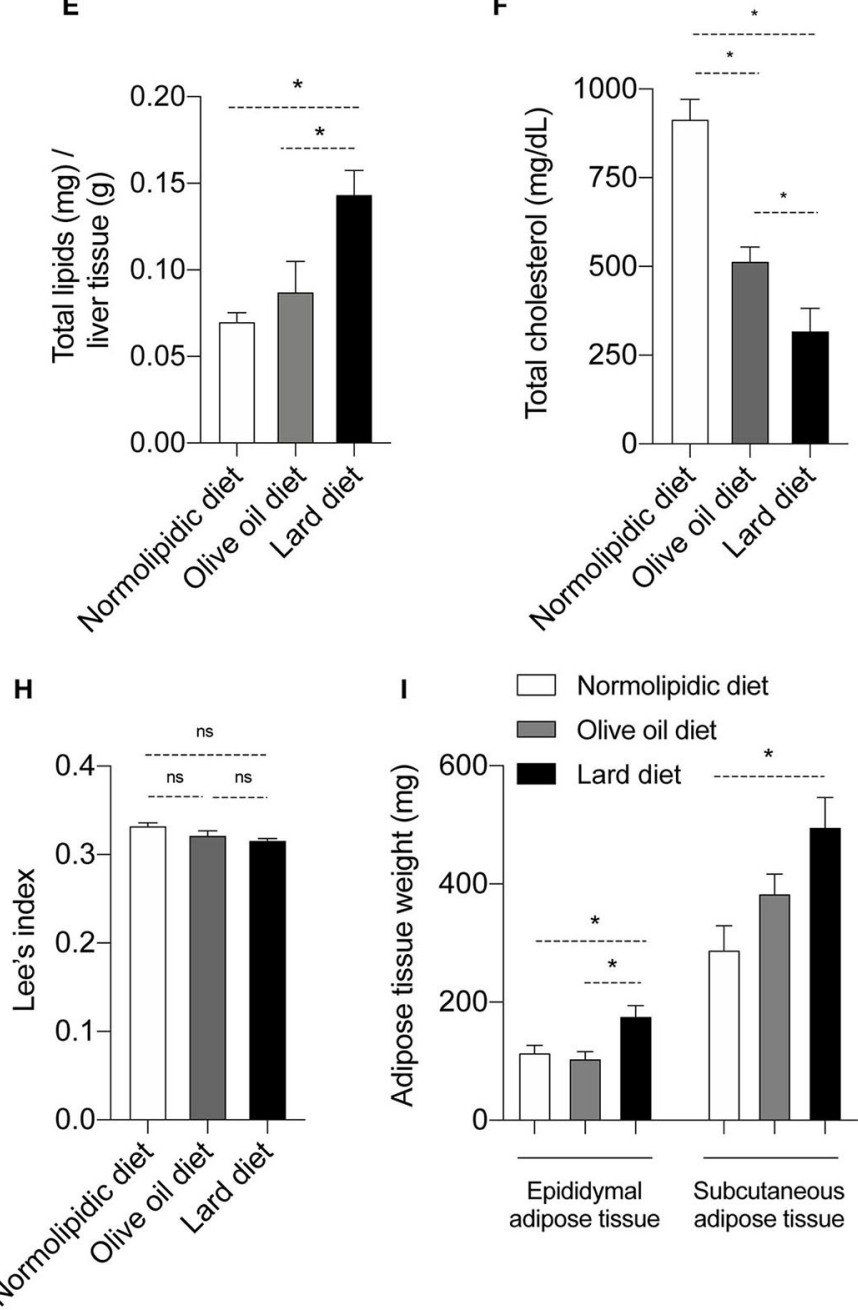

FIGURE 1 | Body and biochemical parameters from mice fed with different types of hyperlipidic diets. Newly weaned C57BL/6 mice were fed with either a normolipidic diet $(n=8)$, monounsaturated fatty acid diet with olive oil $(n=8)$ or saturated fatty acid diet with lard $(n=8)$ and $(\mathbf{A})$ the body weight was monitored weekly in a digital scale. The (B) food intake and the (C) calorie intake were calculated every other day. At the day 90th of diet, mice were euthanized and (D) the liver/body weight ratio, (E) liver total lipids levels, (F) plasma total cholesterol, (G) plasma triglycerides, (H) Lee's index and (I) weight of adipose tissue were evaluated. ns, not statistically different, ${ }^{*} p<0.05$ by one-way ANOVA followed by Tukey post-hoc test. 

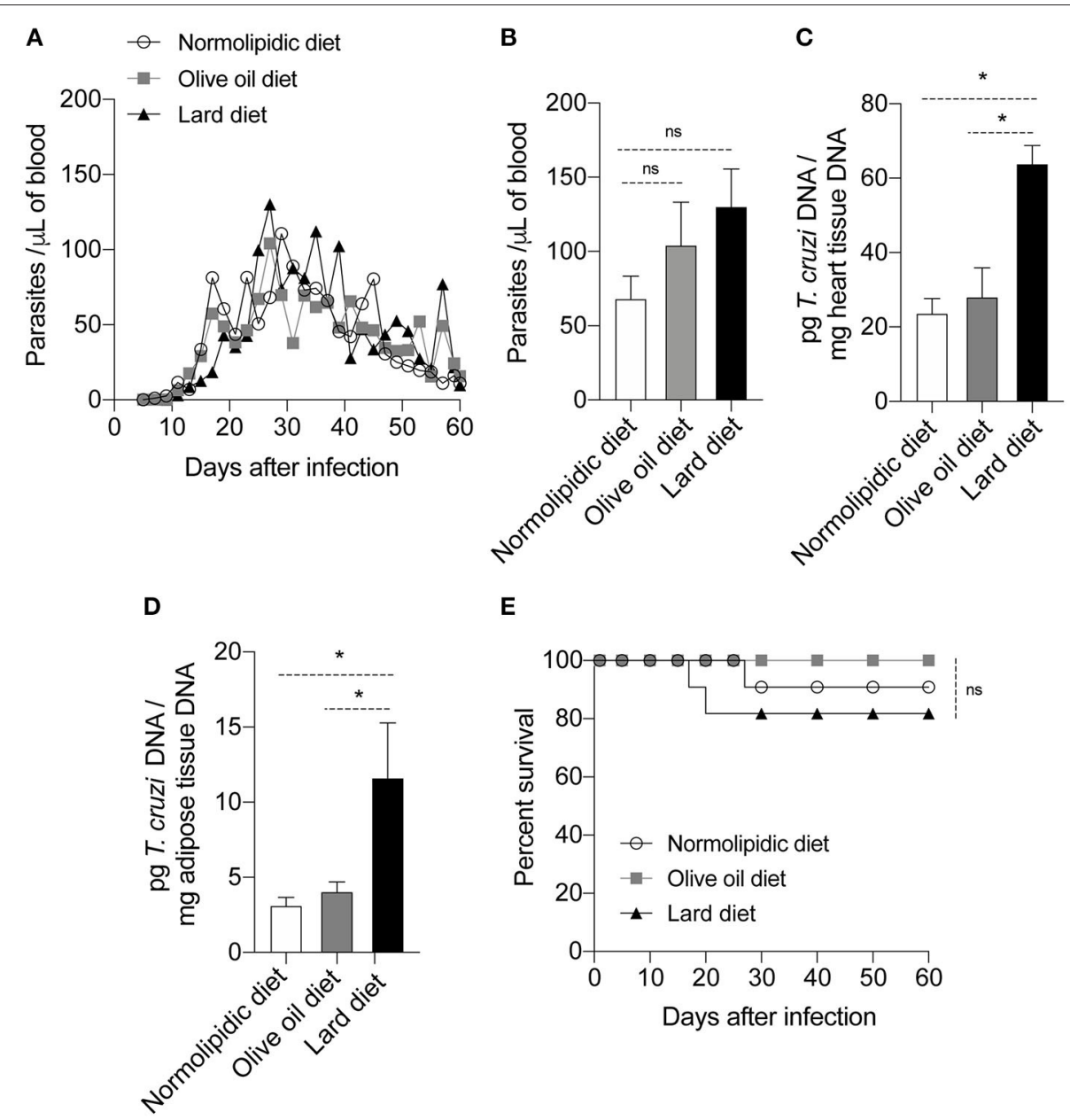

E

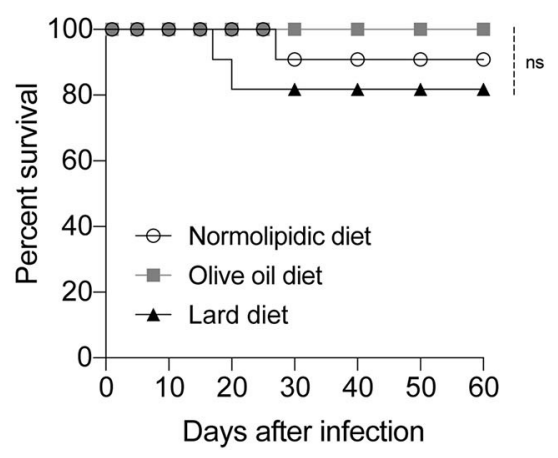

FIGURE 2 | Parasitism and survival rate of mice fed with different types of hyperlipidic diets. Newly weaned C57BL/6 mice were fed with either a normolipidic diet $(n=$ 8), monounsaturated fatty acid diet with olive oil $(n=8)$ or saturated fatty acid diet with lard $(n=8)$. At the day 60 of diet, mice were intraperitoneally infected with 50 blood trypomastigote forms of T. cruzi Colombian strain and (A) the blood parasite levels were monitored daily. (B) Number of parasites circulating in the mice blood at the day 27 after infection. At the day 30 post infection the DNA was extracted from (C) the heart and (D) adipose tissue and the amount of DNA from parasites were quantified in the tissues by real time PCR assay. (E) The survival rate of mice fed with normolipidic diet, olive oil diet or lard diet was monitored daily for 35 days. ns, not statistically different; ${ }^{*} p<0.05$ by one-way ANOVA followed by Tukey post-hoc test.

significantly downregulated the GSH/GSSG ratio in a dietindependent manner (Figure 6A). In response to the parasiteinduced oxidative stress, we observed a slight decreased in the CAT activity in mice under normolipidic or olive oil diets, while infected mice under lard diet presented with intense reduction of catalase activity (Figure 6B). In addition, SOD is important for the protection of cells from oxidative insults, and we observed increases in SOD activity after $30 \mathrm{dpi}$. This increase was independent of the dietary type (Figure 6C).

\section{DISCUSSION}

The ingested lipids in foods are essential elements that impacts the inflammatory profile or alter the redox status caused by the inflammation (19). Diet exerts an important role during the inflammatory processes, with some nutritional studies demonstrating that ample and restricted consumption of monounsaturated and saturated lipids, respectively, decreases the expression of low-grade inflammatory markers $(20,21)$. The effects of a high fat diet in inflammation caused by $T$. cruzi are partially known $(22,23)$, but the effects of different types of lipids remain poorly studied.

Although high consumption of saturated fatty acids is frequently associated with weight gain and obesity in humans and experimental models $(24,25)$, we did not observe alterations in the body or liver weights in our lard group compared with olive oil and normolipidic dietary groups. Our results were consistent with other studies that have shown that few weeks under high fat diet rich in saturated lipids do not increase the body weight in experimental models $(26,27)$. Interestingly, Marques and collaborators showed that the dietinduced weight gain depends on the strain of rats and some 

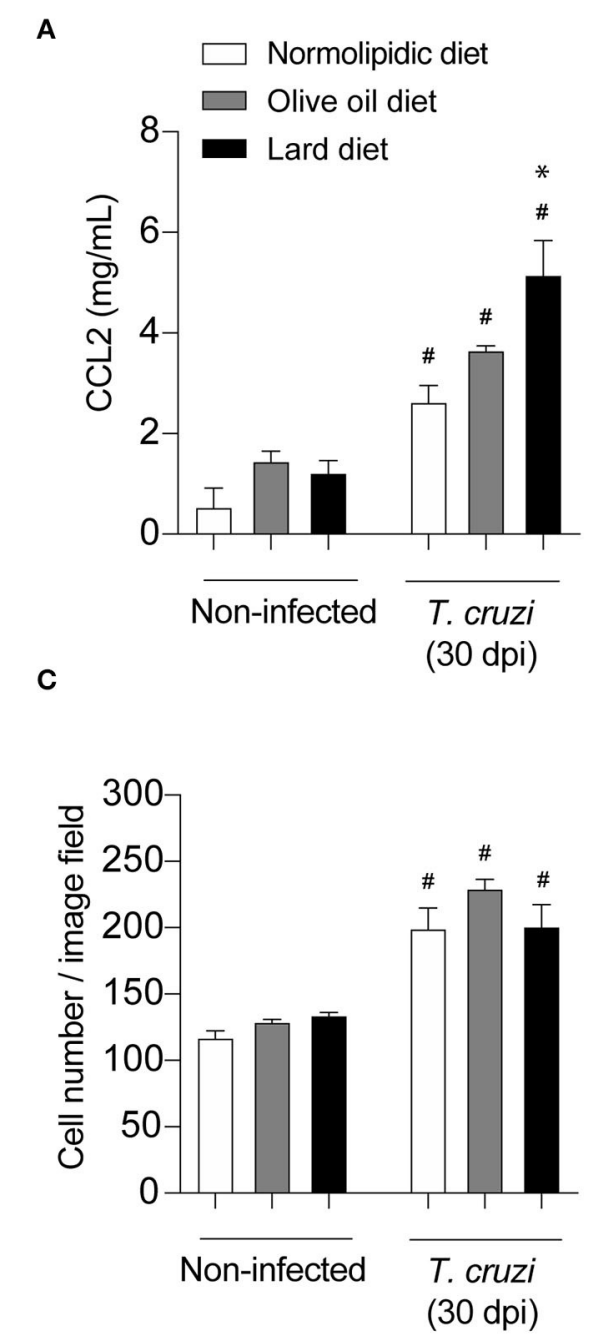

B

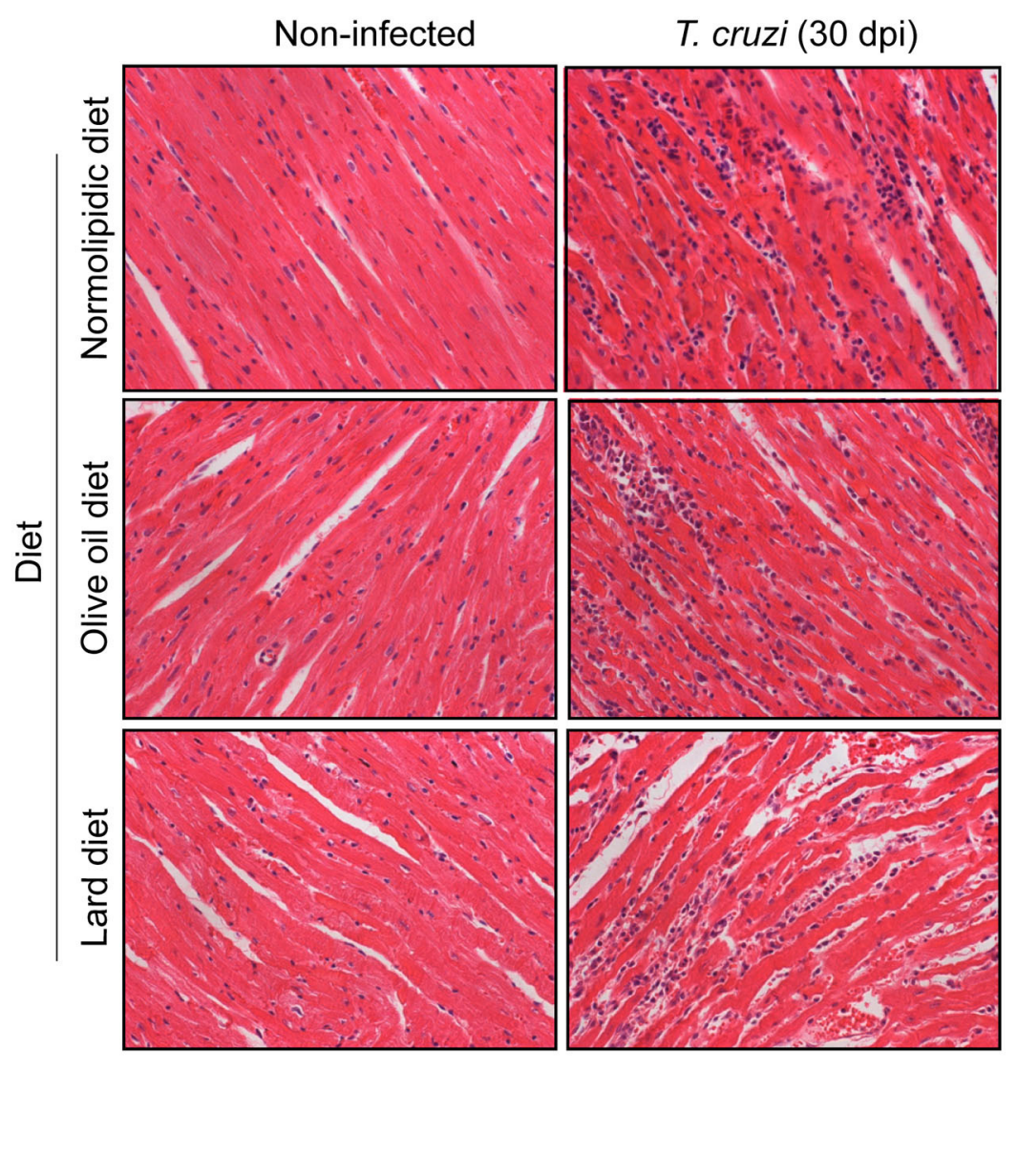

FIGURE 3 | Cardiac inflammatory parameters of T. cruzi infected mice fed with different types of hyperlipidic diets. Newly weaned C57BL/6 mice were fed with either a normolipidic diet $(n=8)$, monounsaturated fatty acid diet with olive oil $(n=8)$ or saturated fatty acid diet with lard $(n=8)$. At the day 60 of diet, mice were intraperitoneally infected with 50 blood trypomastigote forms of T. cruzi Colombian strain. After 30 dpi (A) the concentration of CCL2 was assessed in the heart tissue by ELISA assay. (B) The heart tissue was fixed, processed, blocked in paraffin, cut, and stained with hematoxylin and eosin and (C) the number of cells in the tissue was quantified. ${ }^{\#} p<0.05$ compared with the non-infected group and ${ }^{*} p<0.05$ compared with infected normolipidic diet group by one-way ANOVA followed by Tukey post-hoc test.

strains require longer exposure to the diets to gain weight (28). Although the weight was comparable across dietary groups, the lard diet increased the liver lipid deposition. This could indicate hepatic steatosis commonly observed after hyperlipidic diets (11). In addition, there are unclear points that limit the interpretation of rodent lipid metabolism with the same optical prism used to humans (29). Of note, the majority of human plasma cholesterol is transported as low-density lipoproteins (LDL), but mice do not have cholesteryl ester transfer protein, and for this reason, significant amounts of cholesterol are identified as high-density lipoproteins (HDL) in these animals. Another point, when animals have a high consumption of carbohydrates (e.g., normolipidic diet - AIN$93 \mathrm{M})$, they can modify cholesterol metabolism increasing it in the blood (30), even under a low-lipid diet, as we have shown in this current study.

Hyperlipidic diets discussed here present equal energy density, however, the lard diet is the more efficient in transforming calories into adipose tissue assuming the normolipidic diet as reference. No change was observed in the body composition of animals under the effect of the different diets, according to Lee's index, however, the increased epididymal adipose tissue related to a lard diet may be favoring parasite interaction with host cells due to the presence of saturated fatty acids and the increased cell internalization of cholesterol, as previously demonstrated $(7,31-34)$. Then, considering the cholesterol analogs for the parasite invasion and replication and, considering both olive oil and lard diets have similar total lipid 


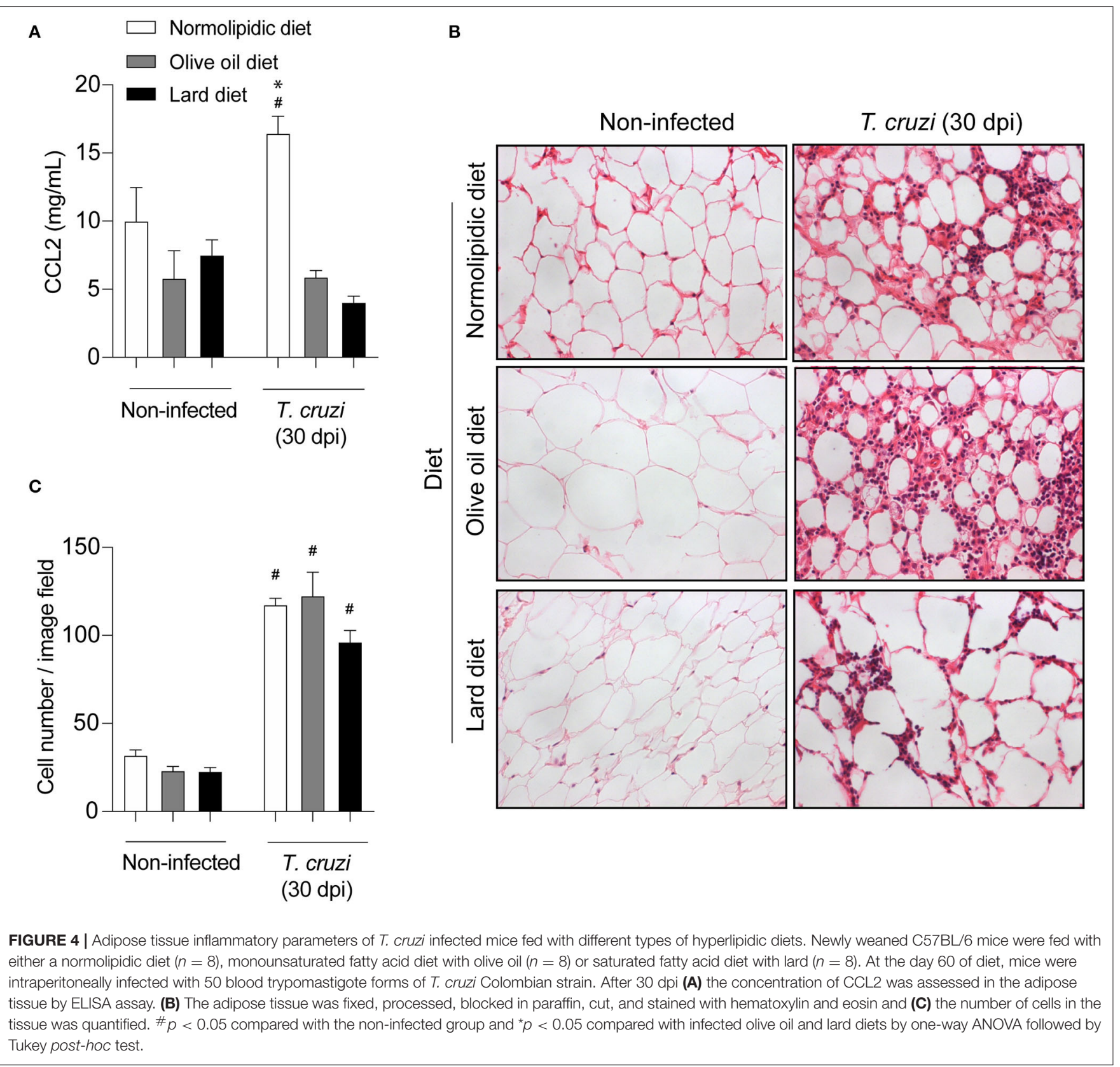

percentage, we supplemented the lard diet with $1 \%$ cholesterol attempting to understand how it could be favorable or not to the T. cruzi.

Previously published results have showed that the T. cruzi infects and proliferates within brown and white adipose tissue $(32,35)$. In accordance with this, we showed that, although the blood parasitemia was the same in mice from the hyperlipidic and normolipidic dietary groups, mice under lard diet showed increased parasitism in both the adipose and cardiac tissues. Despite high tissue parasitism, the survival rate was the same among all dietary groups. In contrast, using the Brazil strain of $T$. cruzi, Nagajyothi et al. demonstrated that a high fat diet increases survival rate in infected mice (7). Of note, studies involving $T$. cruzi must pay attention to the strain used. A limitation of our study was that, given that mice fed a normolipidic diet survived the infection with the Colombian strain, we were not able to observe higher survival rates in infected animals from the other dietary groups.

Chemokine production and tissue recruitment of inflammatory cells in T. cruzi infected animals are essential for proper parasite control (36). In fact, our findings demonstrated an increase in heart CCL2 expression and the number of inflammatory cells in the heart and adipose tissues following infection in all dietary groups. Although 
A

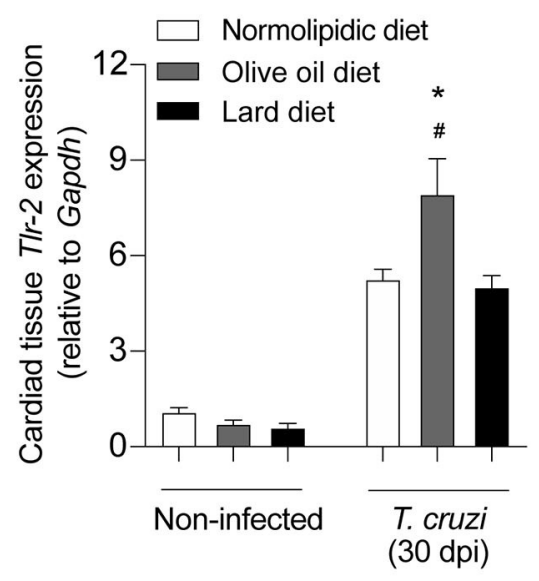

C

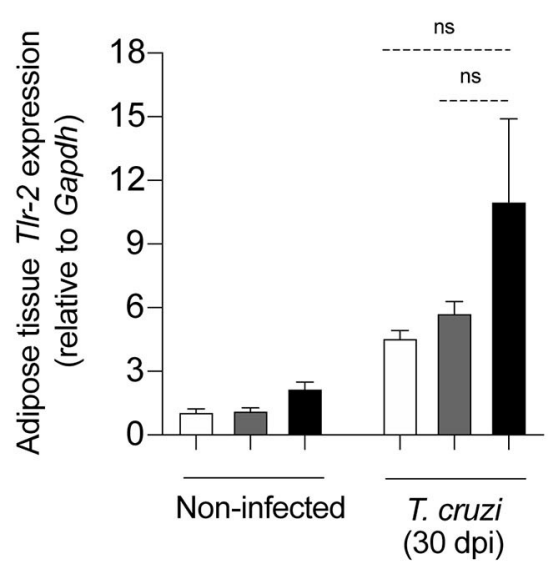

B

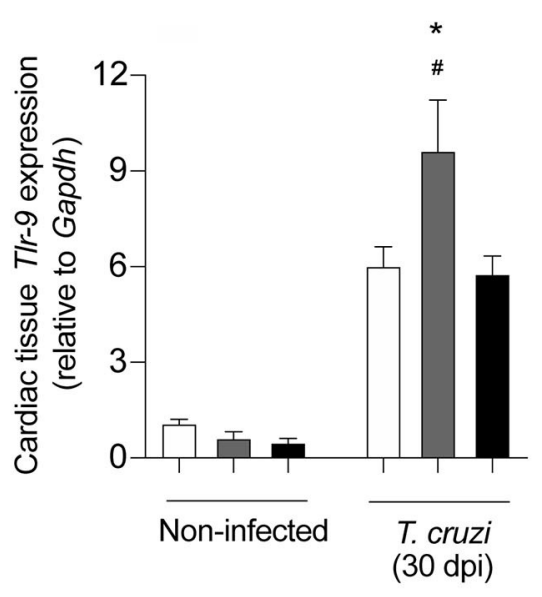

D

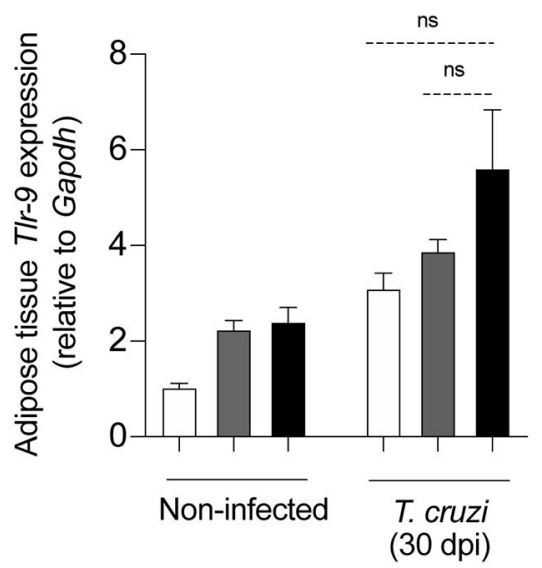

FIGURE 5 | TLRs expression on the heart and adipose tissue from T. cruzi infected mice fed with different types of hyperlipidic diets. Newly weaned C57BL/6 mice were fed with either a normolipidic diet $(n=5)$, monounsaturated fatty acid diet with olive oil $(n=5)$ or saturated fatty acid diet with lard $(n=5)$. At the day 60 of diet, mice were intraperitoneally infected with 50 blood trypomastigote forms of T. cruzi Colombian strain. After 30 dpi the mRNA expression levels of T/r2 and T/r9 were measured in the heart $(\mathbf{A}, \mathbf{B})$ and adipose tissue $\mathbf{( C , D )}$ by real time quantitative PCR. Gapdh and $18 \mathrm{~S}$ were used as housekeeping genes for the heart and adipose tissues, respectively. ns, not statistically different. ${ }^{*} p<0.05$ compared with the non-infected group and ${ }^{*} p<0.05$ compared with infected group by one-way ANOVA followed by Tukey post-hoc test.

an increase in CCL2-producing macrophages is expected in the adipose tissues of infected mice (37), mice from lard dietary group presented with adipose tissue inflammation, independent of CCL2 production. Worth highlighting that caloric restriction has been shown to reduces migration of peripheral inflammatory monocytes from the bone marrow to the circulation and tissues by interference on the CCL2 production in a mechanism dependent on the peroxisome proliferator-activator receptor alpha and the activated protein kinase (38). In our study, animals fed with normolipidic performed higher ingestion of food in relation to those feed with olive oil or lard diets, however without differences in the calorie intake. In addition, the lard diet promoted a higher parasites load in both evaluated sites evaluated with the distinct pattern of CCL2 expression, after $48 \mathrm{~h}$ of the peak of parasitemia concerning Colombian strain of T. cruzi. At this representative moment of the experimental T. cruzi infection, no difference in inflammatory infiltration was detected through histological sections, but based on our previous experience, higher expression of CCL2 represents a higher release of this chemokine, an increasing of leukocyte recruitment, higher cardiac tissue damage and mortality in those infected animals (39).

Also essential to parasite control by immune cells is the recognition of $T$. cruzi structures by cellular receptors. The importance of TLR-2 and TLR-9 during the T. cruzi infection was previously reported (40). Our results demonstrated an overexpression of Tlr2 and Tlr 9 mRNA in adipose tissue 
A

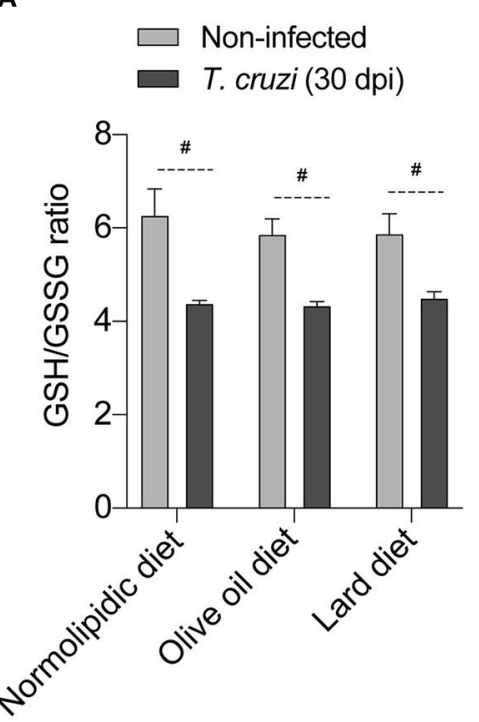

B

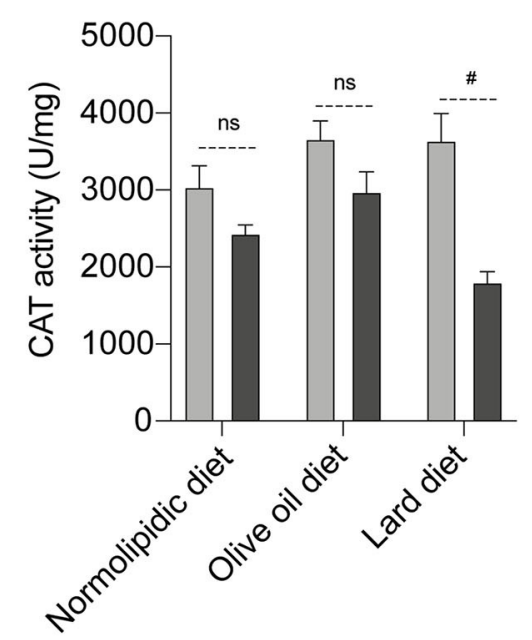

C

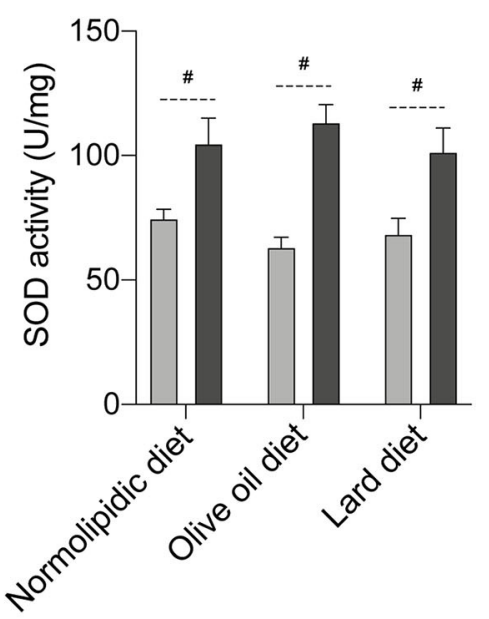

FIGURE 6 | Redox status of T. cruzi infected mice fed with different types of hyperlipidic diets. Newly weaned C57BL/6 mice were fed with either a normolipidic diet ( $n$ $=5)$, monounsaturated fatty acid diet with olive oil $(n=5)$ or saturated fatty acid diet with lard $(n=5)$. At the day 60 of diet, mice were intraperitoneally infected with 50 blood trypomastigote forms of T. cruzi Colombian strain. After 30 dpi (A) the GSH/GSSG ratio, (B) CAT activity and (C) SOD activity were measured in the supernatant of a macerated piece of liver. GSH, reduced glutathione; GSSH, oxidized glutathione; CAT, catalase; SOD, superoxide dismutase; ns, not statistically different; $\# p<0.05$ by student $t$-test.

and in cardiac tissue driven by lard and olive oil diets, respectively. Recent evidence suggest that saturated fatty acids can promote TLR-2 and TLR- 4 activation while polyunsaturated fatty acids can inhibit these receptors (41). In parallel, T. cruziglycosylphosphatidylinositol membrane anchor is recognized by both, TLR-2 and TLR-9, and exert a role in the prognosis of asymptomatic and cardiac clinical forms of Chagas disease (42). In note, T. cruzi infection increases $T l r 2$ and $T l r 9$ expression in brown and white adipose tissues, respectively, as well as in other immune cells (43), and, together, they act in the balance between modulatory and inflammatory responses. This duality observed in the expression of Tlr2 and Tlr9 under high-fat diets effects might interfere in the parasite-host interaction and the immunopathogenesis since the deficiency of these receptors or of the Myd88 promotes susceptibility in infected mice (40) or the activation of TLR2 and NF-Kb triggers cardiomyocyte hypertrophy (44, 45). Remarkably, the toll-like receptors act as a bridge between diet-induced endocrine and immune response, but further investigations are necessary to better understand this network.

Finally, both lipid-rich diets and T. cruzi infection cause oxidative stress $(46,47)$, and consequently, require the regulation of the antioxidant levels to reduce the high free radicals levels. The parasite decreases the GSH/GSSG ratio and CAT activity and increases SOD activity increasing the oxidative stress $(48,49)$. Interestingly, and in accordance with previous published data (23), our mice fed with saturated lipid-rich diet showed decreased CAT activity compared with mice from the normolipidic and unsaturated lipid-rich dietary groups. The antioxidant CAT rescues the cardiac dysfunction induced by high fat diets in mice (50). This suggests that the reduced CAT levels during infection may contribute to parasite-caused cardiac pathogenesis.

In summary, our findings provided evidence that diets rich in saturated lipids (e.g., lard diet) promote growth of T. cruzi in tissues following infection, and decrease the liver antioxidant production, contributing to the tissue damage.

\section{DATA AVAILABILITY STATEMENT}

The raw data supporting the conclusions of this article will be made available by the authors, without undue reservation.

\section{ETHICS STATEMENT}

The animal study was reviewed and approved by Animal Research Ethics Committee of the Federal University of Ouro Preto (CEUA-UFOP), under protocol number 36/2015.

\section{AUTHOR CONTRIBUTIONS}

DMSS, MCS, and AT: design, writing, and final content. DMSS, SEBF, APJM, CMM, KPL, NCNP, PMA, DCC, and GPC: performed the experiments. DMSS, MCS, and KMCP: data analysis. JSS and AT: funding acquisition. All authors have read and approved the final version of this manuscript. 


\section{FUNDING}

This research was supported by CNPq, CAPES, and FAPEMIG funding agencies in Brazil as well as the Universidade Federal

\section{REFERENCES}

1. Pérez-Molina JA, Molina I. Chagas disease. Lancet. (2018) 391:82-94. doi: 10.1016/S0140-6736(17)31612-4

2. Coura JR, Borges-Pereira J. Chagas disease: 100 years after its discovery. A systemic review. Acta Trop. (2010) 115:513. doi: 10.1016/j.actatropica.2010.03.008

3. Brener Z, Gazzinelli RT. Immnunological control of Trypanosoma cruzi infection and pathogenesis of Chagas' disease. Int Arch Allergy Immunol. (1997) 114:103-10. doi: 10.1159/000237653

4. Rassi A, Rassi A, Little WC. Chagas' heart disease. Clin Cardiol. (2000) 23:883-9. doi: 10.1002/clc.4960231205

5. Duque TLA, Cascabulho CM, Oliveira GM, Henriques-Pons A, Menna-Barreto RFS. Rapamycin treatment reduces acute myocarditis induced by Trypanosoma cruzi infection. J Innate Immun. (2020) 12:321-32. doi: 10.1159/000504322

6. Molina I, Salvador F, Sánchez-Montalvá A, Treviño B, Serre N, Avilés AS, et al. Toxic profile of benznidazole in patients with chronic chagas disease: risk factors and comparison of the product from two different manufacturers. Antimicrob Agents Chemother. (2015) 59:612531. doi: 10.1128/AAC.04660-14

7. Nagajyothi F, Weiss LM, Zhao D, Koba W, Jelicks LA, Cui MH, et al. High fat diet modulates Trypanosoma cruzi infection associated myocarditis. PLoS Negl Trop Dis. (2014) 8:e3118. doi: 10.1371/journal.pntd.0003118

8. Carvalho LSC, Camargos ERS, Almeida CT, Peluzio M do CG, AlvarezLeite JI, Chiari E, et al. Á. Vitamin E deficiency enhances pathology in acute Trypanosoma cruzi-infected rats. Trans R Soc Trop Med Hyg. (2006) 100:1025-31. doi: 10.1016/j.trstmh.2005.12.009

9. De Castilhos MP, Huguenin GVB, Rodrigues PRM, Do Nascimento EM, Pereira B de B, Pedrosa RC. Diet quality of patients with chronic chagas disease in a tertiary hospital: a case-control study. Rev Soc Bras Med Trop. (2017) 50:795-804. doi: 10.1590/0037-8682-0237-2017

10. Milanski M, Degasperi G, Coope A, Morari J, Denis R, Cintra $\mathrm{DE}$, et al. Saturated fatty acids produce an inflammatory response predominantly through the activation of TLR4 signaling in hypothalamus: implications for the pathogenesis of obesity. J Neurosci. (2009) 29:359-70. doi: 10.1523/JNEUROSCI.2760-08.2009

11. Figueiredo VP, Junior ESL, Lopes LR, Simões NF, Penitente AR, Bearzoti E, et al. High fat diet modulates inflammatory parameters in the heart and liver during acute Trypanosoma cruzi infection. Int Immunopharmacol. (2018) 64:192-200. doi: 10.1016/j.intimp.2018.08.036

12. Lovo-Martins MI, Malvezi AD, da Silva RV., Zanluqui NG, Tatakihara VLH, Câmara NOS, et al. Fish oil supplementation benefits the murine host during the acute phase of a parasitic infection from Trypanosoma cruzi. Nutr Res. (2017) 41:73-85. doi: 10.1016/j.nutres.2017.04.007

13. Medeiros-De-Moraes IM, Gonçalves-De-Albuquerque CF, Kurz ARM, De Jesus Oliveira FM, Pereira de Abreu VH, Torres RC, et al. Omega-9 oleic acid, the main compound of olive oil, mitigates inflammation during experimental sepsis. Oxid Med Cell Longev. (2018) 2018:6053492. doi: 10.1155/2018/6053492

14. Lee MO. Determination of the surface area of the white rat with its application to the expression of metabolic results. Am J Physiol Content. (1929) 89:2433. doi: 10.1152/ajplegacy.1929.89.1.24

15. Bernardis LL, Patterson BD. Correlation between "Lee index" and carcass fat content in weanling and adult female rats with hypothalamic lesions. $J$ Endocrinol. (1968) 40:527-8. doi: 10.1677/joe.0.0400527

16. Cummings KL, Tarleton RL. Rapid quantitation of Trypanosoma cruzi in host tissue by real-time PCR. Mol Biochem Parasitol. (2003) 129:539. doi: 10.1016/S0166-6851(03)00093-8

17. Aebi H. Catalase in vitro. Methods Enzymol. (1984) 105:1216. doi: 10.1016/S0076-6879(84)05016-3 de Ouro Preto (UFOP, Brazil). JSS was grateful to FAPESP (Grant Agreement Number 2013/08216-2-Center for Research in Inflammatory Disease-CRID). AT (Process \# 305634/2017-8) and JSS (Process \# 308490/2014-5) were greateful to CNPq.

18. Rogers P, Webb GP. Estimation of body fat in normal and obese mice. $\mathrm{Br} \mathrm{J}$ Nutr. (1980) 43:83-6. doi: 10.1079/BJN19800066

19. López-Muñoz RA, Molina-Berríos A, Campos-Estrada C, Abarca-Sanhueza P, Urrutia-Llancaqueo L, Peña-Espinoza M, et al. Inflammatory and proresolving lipids in trypanosomatid infections: a key to understanding parasite control. Front Microbiol. (2018) 9:1961. doi: 10.3389/fmicb.2018.01961

20. Kolehmainen M, Ulven SM, Paananen J, De Mello V, Schwab U, Carlberg $\mathrm{C}$, et al. Healthy Nordic diet downregulates the expression of genes involved in inflammation in subcutaneous adipose tissue in individuals with features of the metabolic syndrome. Am J Clin Nutr. (2015) 101:22839. doi: 10.3945/ajcn.114.092783

21. Uusitupa M, Hermansen K, Savolainen MJ, Schwab U, Kolehmainen M, Brader L, et al. Effects of an isocaloric healthy Nordic diet on insulin sensitivity, lipid profile and inflammation markers in metabolic syndrome - a randomized study (SYSDIET). J Intern Med. (2013) 274:5266. doi: 10.1111/joim. 12044

22. Tanowitz HB, Machado FS, Spray DC, Friedman JM, Weiss OS, Lora JN, et al. Developments in the management of Chagas cardiomyopathy. Expert Rev Cardiovasc Ther. (2015) 13:1393-409. doi: 10.1586/14779072.2015.1103648

23. Ayyappan JP, Nagajyothi JF. Diet modulates adipose tissue oxidative stress in a murine acute chagas model. JSM Atheroscler. (2017) 2:1030.

24. Corella D, Arnett DK, Tucker KL, Kabagambe EK, Tsai M, Parnell LD, et al. A high intake of saturated fatty acids strengthens the association between the fat mass and obesity-associated gene and BMI. J Nutr. (2011) 141:221925. doi: 10.3945/jn.111.143826

25. Viggiano E, Mollica M, Lionetti L, Cavaliere G, Trinchese G, Filippo C, et al. Effects of an high-fat diet enriched in lard or in fish oil on the hypothalamic amp-activated protein kinase and inflammatory mediators. Front Cell Neurosci. (2016) 10:150. doi: 10.3389/fncel.2016.00150

26. Wang Y, Dellatore P, Douard V, Qin L, Watford M, Ferraris RP, et al. High fat diet enriched with saturated, but not monounsaturated fatty acids adversely affects femur, and both diets increase calcium absorption in older female mice. Nutr Res. (2016) 36:742-50. doi: 10.1016/j.nutres.2016.03.002

27. Song Z, Xie W, Chen S, Strong JA, Print MS, Wang JI, et al. High-fat diet increases pain behaviors in rats with or without obesity. Sci Rep. (2017) 7:10350. doi: 10.1038/s41598-017-10458-z

28. Marques C, Meireles M, Norberto S, Leite J, Freitas J, Pestana D, et al. High-fat diet-induced obesity rat model: a comparison between Wistar and Sprague-Dawley rat. Adipocyte. (2016) 5:11-21. doi: 10.1080/21623945.2015.1 061723

29. Bergen WG, Mersmann HJ. Comparative aspects of lipid metabolism: impact on contemporary research and use of animal models. J Nutr. (2005) 135:2499502. doi: 10.1093/jn/135.11.2499

30. Parhofer KG. Interaction between glucose and lipid metabolism: more than diabetic dyslipidemia. Diabetes Metab J. (2015) 39:353-62. doi: 10.4093/dmj.2015.39.5.353

31. Nagajyothi F, Desruisseaux MS, Machado FS, Upadhya R, Zhao D, Schwartz GJ, et al. Response of adipose tissue to early infection with Trypanosoma cruzi (Brazil strain). J Infect Dis. (2012) 205:830-40. doi: 10.1093/infdis/jir840

32. Matos Ferreira AV, Segatto M, Menezes Z, Macedo AM, Gelape C, de Oliveira Andrade L, et al. Evidence for Trypanosoma cruzi in adipose tissue in human chronic Chagas disease. Microbes Infect. (2011) 13:10025. doi: 10.1016/j.micinf.2011.06.002

33. Johndrow C, Nelson R, Tanowitz H, Weiss LM, Nagajyothi F. Trypanosoma cruzi infection results in an increase in intracellular cholesterol. Microbes Infect. (2014) 16:337-44. doi: 10.1016/j.micinf.2014.01.001

34. Tanowitz HB, Jelicks LA, Machado FS, Esper L, Qi X, Desruisseaux MS, et al. Adipose tissue, diabetes and chagas disease. Adv Parasitol. (2011) 76:235-50. doi: 10.1016/B978-0-12-385895-5.00010-4

35. Combs TP, Nagajyothi, Mukherjee S, De Almeida CJG, Jelicks LA, Schubert $\mathrm{W}$, et al. The adipocyte as an important target cell for Trypanosoma 
cruzi infection. J Biol Chem. (2005) 280:24085-94. doi: 10.1074/jbc. M412802200

36. Talvani A, Ribeiro CS, Aliberti JCS, Michailowsky V, Santos PVA, Murta SMF, et al. Kinetics of cytokine gene expression in experimental chagasic cardiomyopathy: tissue parasitism and endogenous IFN$\gamma$ as important determinants of chemokine mRNA expression during infection with Trypanosoma cruzi. Microbes Infect. (2000) 2:851-66. doi: 10.1016/S1286-4579(00)00388-9

37. Cabalén ME, Cabral MF, Sanmarco LM, Andrada MC, Onofrio LI, Ponce NE, et al. Chronic Trypanosoma cruzi infection potentiates adipose tissue macrophage polarization toward an anti-inflammatory M2 phenotype and contributes to diabetes progression in a diet-induced obesity model. Oncotarget. (2016) 7:13400-15. doi: 10.18632/oncotarget.7630

38. Jordan S, Tung N, Casanova-Acebes M, Chang C, Cantoni C, Zhang D, et al. Dietary intake regulates the circulating inflammatory monocyte pool. Cell. (2019) 178:1102-14.e17. doi: 10.1016/j.cell.2019.07.050

39. Shrestha D, Bajracharya B, Paula-Costa G, Salles BC, Leite ALJ, Menezes APJ, et al. Expression and production of cardiac angiogenic mediators depend on the Trypanosoma cruzi-genetic population in experimental C57BL/6 mice infection. Microvasc Res. (2017) 110:56-63. doi: 10.1016/j.mvr.2016.12.002

40. Bafica A, Santiago HC, Goldszmid R, Ropert C, Gazzinelli RT, Sher A. Cutting edge: TLR9 and TLR2 signaling together account for MyD88-dependent control of parasitemia in Trypanosoma cruzi infection. J Immunol. (2006) 177:3515-9. doi: 10.4049/jimmunol.177.6.3515

41. Huang S, Rutkowsky JM, Snodgrass RG, Ono-Moore KD, Schneider DA, Newman JW, et al. Saturated fatty acids activate TLRmediated proinflammatory signaling pathways. J Lipid Res. (2012) 53:2002-13. doi: 10.1194/jlr.D029546

42. Mendes da Silva LD, Gatto M, Miziara de Abreu Teodoro M, de Assis Golim M, Pelisson Nunes da Costa A, Capel Tavares Carvalho F, et al. Participation of TLR2 and TLR4 in cytokines production by patients with symptomatic and asymptomatic chronic Chagas disease. Scand J Immunol. (2017) 85:5865. doi: $10.1111 /$ sji.12501

43. Gravina HD, Antonelli L, Gazzinelli RT, Ropert C. Differential use of TLR2 and TLR9 in the regulation of immune responses during the infection with Trypanosoma cruzi. PLoS ONE. (2013) 8:e63100. doi: 10.1371/journal.pone.0063100

44. Higashikuni Y, Tanaka K, Kato M, Nureki O, Hirata Y, Nagai R, et al. Tolllike receptor-2 mediates adaptive cardiac hypertrophy in response to pressure overload through interleukin- $1 \beta$ upregulation via nuclear factor $\mathrm{\kappa} B$ activation. J Am Heart Assoc. (2013) 2:e000267. doi: 10.1161/JAHA.113.000267

45. Ferenčić A, Cuculić D, Stemberga V, Šešo B, Arbanas S, Jakovac H. Left ventricular hypertrophy is associated with overexpression of HSP60, TLR2, and TLR4 in the myocardium. Scand J Clin Lab Invest. (2020) 80:23646. doi: 10.1080/00365513.2020.1725977

46. Den Hartigh LJ, Han CY, Wang S, Omer M, Chait A. 10E,12Z-conjugated linoleic acid impairs adipocyte triglyceride storage by enhancing fatty acid oxidation, lipolysis, and mitochondrial reactive oxygen species. J Lipid Res. (2013) 54:2964-78. doi: 10.1194/jlr.M035188

47. Wen JJ, Nagajyothi F, Machado FS, Weiss LM, Scherer PE, Tanowitz HB, Garg NJ. Markers of oxidative stress in adipose tissue during Trypanosoma cruzi infection. Parasitol Res. (2014) 113:3159-65. doi: 10.1007/s00436-01 4-3977-7

48. Souza ABF, Chírico MTT, Cartelle CT, Costa GP, Talvani A, Cangussú SD, et al. High-fat diet increases HMGB1 expression and promotes lung inflammation in mice subjected to mechanical ventilation. Oxid Med Cell Longev. (2018) 2018:7457054. doi: 10.1155/2018/7457054

49. Santos RS, Silva PL, Oliveira GP, Cruz FF, Ornellas DS, Morales MM, et al. Effects of oleanolic acid on pulmonary morphofunctional and biochemical variables in experimental acute lung injury. Respir Physiol Neurobiol. (2011) 179:129-36. doi: 10.1016/j.resp.2011.07.008

50. Liang L, Shou XL, Zhao HK, Ren G qun, Wang JB, Wang XH, et al. Antioxidant catalase rescues against high fat diet-induced cardiac dysfunction via an IKK $\beta$-AMPK-dependent regulation of autophagy. Biochim Biophys Acta Mol Basis Dis. (2015) 1852:343-52. doi: 10.1016/j.bbadis.201 4.06.027

Conflict of Interest: The authors declare that the research was conducted in the absence of any commercial or financial relationships that could be construed as a potential conflict of interest.

Copyright ( 2021 Souza, Silva, Farias, Menezes, Milanezi, Lúcio, Paiva, Abreu, Costa, Pinto, Costa, Silva and Talvani. This is an open-access article distributed under the terms of the Creative Commons Attribution License (CC BY). The use, distribution or reproduction in other forums is permitted, provided the original author(s) and the copyright owner(s) are credited and that the original publication in this journal is cited, in accordance with accepted academic practice. No use, distribution or reproduction is permitted which does not comply with these terms. 